\title{
METHODOLOGICAL APPROACHES TO THE ANALYSIS OF THE IMPLEMENTATION OF THE "CENTER-REGION" RELATIONS TAKING INTO ACCOUNT ECONOMIC AND ENVIRONMENTAL SECURITY
}

\author{
Tetiana Somkina ${ }^{1}$, Olena Tarasevych ${ }^{2}$
}

\begin{abstract}
The article considers the issues of environmental and economic security of the region within the socio-economic development of society, taking into account the conceptual approaches to the application of basic parameters and indicators for determining the level of economic security of the country. The purpose of this article is to systematize conceptual approaches to determining the parameters of achieving economic security of regional development within the socio-economic system of society in terms of creating effective relations of organizational and functional interaction of "center-region" relations taking into account the current stage of economic development of Donetsk oblast, Ukraine. Improving the processes of management of the formation of "center - region" relations is based on the study and use of laws and patterns of regional socioeconomic development to identify forms of their implementation, which allows to achieve qualitative change in environmental and economic parameters of the region. Ensuring the socio-economic development of society is possible by improving the management of the formation of relations "center - region", based on the study and use of laws and patterns of regional socio-economic development, identifying forms of their implementation to achieve qualitative change in environmental and economic parameters development of the region. The study of issues of management of the processes of "center - region" relations in the presence of the influence of destabilizing factors becomes an urgent task of ensuring the security of the modern regional economy within the socio-economic system. Given the great scientific and practical significance of this problem, it is advisable to further study the possibilities of "center - region" relations to ensure economic security of the region, taking into account indicators of the regional component of the socio-economic system.
\end{abstract}

Key words: economic security of the region, socio-economic development of society, "center-region" relations, parameters of economic security, indicators of economic security.

JEL Classification: R11, R13, F52

\section{Introduction}

Nowadays, the decentralization of state influence on all economic processes is growing in most economically developed countries. The most important element of this process is the interaction and relations between the main economic entities, which can be characterized within the "center - region" relations management. In many respects, these relations determine the directions of regional policy, form the conditions for the use of effective mechanisms, tools and methods of governance. This is based on the solution of the problem of economic security of the country through ensuring the environmental, economic and socio-economic security of the regions. The scientific and methodological basis for the study of processes, which is a prerequisite for socioeconomic relations to ensure the environmental and economic security of the region within the economic theory and management theory is the

\footnotetext{
Corresponding author

${ }^{1}$ State University of Telecommunications, Ukraine.

E-mail: t.v.semkina@ukr.net

ORCID: https://orcid.org/0000-0003-2852-2989

${ }^{2} \mathrm{~V}$. Mamutov Institute of Economic and Legal Research

of the National Academy of Sciences of Ukraine, Ukraine.

E-mail: gradoved.iepd@gmail.com

ORCID: https://orcid.org/0000-0002-6016-3608
} 
use of two fundamental principles of subsidiarity (socio-economic and environmental-economic decisions within economic development the state on the principle of using the capabilities of the most competent authority) and fiscal equivalence (efficient use of financial resources of the region through tax revenues). Thus, between the central government and the regions, there are socio-economic relations, which in the most concentrated form are reflected in the distribution of powers in the economic sphere between the state government and regional leadership.

At the same time, a distinctive feature of the global experience of public administration in terms of the formation of "center - region" relations is the strengthening of the regional component, when the regions gain organizational and functional independence, including in planning specific development programs. This requires a study of the peculiarities of the development of environmental and economic systems, taking into account their regional elements are possibly divergent.

The transition to public administration on the principles of "center - region" interaction and relations requires coordinated action in all spheres of society, including the adequate reorientation of social, economic and environmental institutions of the state, so as to ensure the security of the state as a whole and each separate region. In such transformations, the regulatory role of the state is fundamental in terms of ensuring economic security.

The diversity of regions requires unconditional consideration of their specifics in the development and implementation of state policy on the introduction of "center - region" relations. In these context, the responsibility of the regional executive and representative bodies for the effective use of forms and methods of state influence on environmental and economic development to ensure positive dynamics in the socio-economic sphere increases significantly. This is the basis for the implementation of interaction and relations in order to increase the role of the region in the functioning of the socio-economic system of society.

Issues of economic security of the regional development from the point of view of public administration and related processes of decentralization of management decisions have been in the sphere of systemic attention of economists around the world since the end of the last century. Many sciences, for example, Heiets V. (2006), Pasternak-Taranushenko H. (2012), Chukhno A. (2007), Bondar O. (2013), Hudzynskyi O. (2014), etc. devote their works to the problems of economic security, but they focus on the global, international and national levels of economic security. Foreign scientists Ansell Ch. (2002), Beer S. (1994), Checkland R. (1976) and many others develop problems related to the strategy of socio-economic development and economic security in the period of economic reforms in different countries.

However, most of the published works of domestic and foreign scientists do not take into account the peculiarities of the socio-economic system of the post-crisis economy and the existence of environmental and economic problems of Donetsk and Luhansk oblasts since 2014 and many other aspects that have a significant impact on socio-economic security of Ukraine. At the same time, the relevance of the paper is determined by the fact that the level of socio-economic security of the region has not yet become a special object of detailed research.

The purpose of this article is to systematize conceptual approaches to determining the parameters of achieving economic security of regional development within the socio-economic system of society in terms of creating effective relations of organizational and functional "centerregion" relations taking into account the current stage of economic development of Donetsk oblast, Ukraine.

\section{Methodological approaches to the study of "center-region" relations taking into account the conditions of Donetsk oblast of Ukraine}

The development of any socio-economic system, in particular its regional component, is a process of interaction of trends and patterns that follow from the characteristics of this system, which results in the self-development of the system as a whole and the region in its structure. At the same time, there are contradictions of external and internal nature, which manifest the contradictions of production relations carried out by individual business entities and affect the pace and direction of the system's development. These contradictions lead to changing in the characteristics of the system both in the direction of its development and the spread of dangerous manifestations of its functioning. However, in terms of system's development, the 
presence of contradictions implies the possibility for developing components of the system and the relationship between them, so that the elimination of certain contradictions leads to the creation of other ones (this process is infinite as long as there is a socio-economic system). The patterns of development of the socioecono-mic system of the state are inherent in any level of this system both in terms of historical develop-ment and in terms of organizational and functional structure (including at the regional level).

Any economic activity is known to arise as the interaction of economic entities operating in the modern economic system; its existence is influenced by a set of positive regulations for resolving various industrial contradictions. Economic activity is carried out in case when the subject of entrepreneurial activity is satisfied with its activities or results of activities. But the result of this economic activity always leads to the emergence and resolution of a number of contradictions. These contradictions arise in the industrial, environmental and social spheres, so the necessary means to resolve them should be achieving a socio-economic balance of interests of different socio-economic actors, otherwise, the accumulation of contradictions due to increased manifestations of dangerous contradictions for economic entities may lead to the destruction of the system. According to some researchers, this is the economic basis for ensuring the safe socioeconomic development of the economy as a whole and each region in particular.

Contradictions of economic interests of different subjects of economic activity are safe for the development of the region's economy in case when the factors that determine them are balanced in resolving contradictions of economic interests. At the same time, the optimal solution for the development of the region's economy is to resolve the contradictions of interests of economic entities by achieving the conditions of the socio-economic system in which the system receives the most effective result, and many of inherent contradictions are in stable equilibrium. The functioning of the system is a process of continuous balancing of contradictions both in terms of production of goods and services needed by the region, and the implementation of the processes of distribution, exchange and consumption. When some of the contradictions are emerging, others are forming, manifesting themselves like some differences from the old parameters; some of the contradictions have already been resolved, reached equilibrium, others are reproduced in a new role, and so on. This process allows certain contradictions to become predominant, which can lead to an unstable equilibrium in which a slight internal or external action of destabilizing factors can lead to the fact that the overall balance is not only disturbed but no longer restored.

Unstable equilibrium can become stable if it coincides with the general trend of the system; otherwise, there is a risk of the system remaining in a state of unstable equilibrium and possible destruction.

Thus, the functional effectiveness of the process of economic security within the development of the socio-economic system is due to the synthesis of aggregate properties of elements of the economic system (including at the regional level), which allows to form a dynamic equilibrium structure with the potential for safe self-organization of structural elements at each of the levels of functional interaction and selfdevelopment, taking into account the purposeful movement defined at the state level within the actual and forecast future.

Systemic management of socio-economic development from the point of view of safety of functioning of both subjects of economic activity, and the state as a whole has not only theoretical but also practical value; the effective use of the potential of the country and its separate regions, achievement of a safe environmental and economic trajectory are possible on the basis of conscious, purposeful actions for effective organizational and managerial structuring of economic and social subsystems.

This can be most clearly traced on the example of the current state of Donetsk oblast and the emergence of problems of "center-region" relations in environmental, economic, and socio-economic development.

Donetsk oblast is going through an extremely difficult period of its development today. Prolonged anti-terrorist operation in the region, systemic crisis in the economy, energy, real sector, high unemployment require decisive action based on careful analysis of existing problems, ensuring consistency and synchronization in the implementation of reforms, as well as assessing their consequences.

The weakness of the economy of Donetsk oblast is the presence of significant structural imbalances. 
In the structure of the industry in 2019, about $86.8 \%$ is accounted for by industries that have a low level of value added (Table 1), namely: mining and quarrying (25.0\%), processing $(61.8 \%)$, of which the production of rubber and plastic products, other non-metallic mineral products, metallurgy (39.1\%), manufacture of coke and refined petroleum products $(8.7 \%)$, mechanical engineering (5.3\%), production of food, beverages and tobacco products (4.3\%), manufacture of basic pharmaceutical products and pharmaceutical preparations (2.2\%), manufacture of chemicals and chemical products $(0.6 \%)$, manufacture of wearing apparel, leather, leather products and other materials $(0.1 \%)$, manufacture of paper and printing (0.1\%) (Holovne upravlinnia statystyky $\mathrm{v}$ Donetskii oblasti, 2020).

In addition, the region is characterized by a low share of small enterprises in total sales (goods, services): in 2018, small enterprises of the region gave $7.5 \%$ of regional sales (in Ukraine 19.2\%) (Prohrama ekonomichnoho i sotsialnoho rozvytku Donetskoi oblasti...). This is due to the high concentration in the field of large industrial enterprises: their share in the total number of enterprises is the highest in Ukraine and is $0.3 \%$ (national average $-0.1 \%$ ).
In 2019 , the average monthly wage increased by $21.4 \%$, real wages increased by $9 \%$. The presence of arrears of wages was a negative phenomenon. The number of registered unemployed persons at the end of the period (according to the state employment service) amounted to 10.8 thousand people (Table 1).

Data presented in Figure 1 indicate that the slow recovery of industrial production since 2016 is due to demand factors, namely: unfavorable world market conditions and underdeveloped domestic market. Falling prices for metallurgical products on the world market, as well as unstable supplies of iron ore, coke and coal due to damage to transport infrastructure lead to a difficult situation in the production of major industrial groups in the region.

In 2018, the total volume of industrial production at comparable prices increased by $2.6 \%$. According to the results of 2019, this indicator grew by $0.3 \%$. The agricultural production index in all categories of farms in 2018 was $90.6 \%$. According to the results of 2019, this figure is at the level of $117.3 \%$, which indicates a significant improvement in agricultural production (Holovne upravlinnia statystyky v Donetskii oblasti, 2019; 2020). The building products index in 2019 is $111.7 \%$, which also indicates improving the production of building products compared to 2018 .

Table 1

The main indicators of socio-economic development of Donetsk oblast in 2019

\begin{tabular}{|c|c|c|c|c|c|}
\hline & \multirow{3}{*}{ Actual 2019} & \multicolumn{4}{|c|}{ Growth (decrease) rate, \% } \\
\hline & & \multicolumn{2}{|c|}{ December 2019 to } & \multirow[b]{2}{*}{2019 to 2018} & \multirow{2}{*}{$\frac{\text { Ref. data: }}{2018 \text { to } 2017}$} \\
\hline & & $\begin{array}{l}\text { November } \\
2019\end{array}$ & $\begin{array}{l}\text { December } \\
2018\end{array}$ & & \\
\hline $\begin{array}{l}\text { The number of registered unemployed persons } \\
\text { at the end of the period (according to the state } \\
\text { employment service), thous persons }\end{array}$ & 10.8 & 112.5 & 99.8 & $\mathrm{x}$ & $\mathrm{x}$ \\
\hline \multicolumn{6}{|l|}{ The average monthly salary of one employee } \\
\hline nominal, UAH & $11586^{1}$ & $98.5^{2}$ & $118.0^{3}$ & $121.4^{4}$ & $125.9^{5}$ \\
\hline real, \% & $\mathrm{x}$ & $98.4^{2}$ & $109.6^{3}$ & $109.0^{4}$ & $111.1^{5}$ \\
\hline Wage arrears, mln UAH & 582.1 & 84.1 & 117.0 & $\mathrm{x}$ & 92.5 \\
\hline Consumer price index & $\mathrm{x}$ & 100.0 & 106.0 & 106.07 & 112.38 \\
\hline Volume of industrial products sold $1, \mathrm{mln} \mathrm{UAH}$ & 264520.4 & $\mathrm{x}$ & $\mathrm{x}$ & $\mathrm{x}$ & $\mathrm{x}$ \\
\hline Industrial production index & $\mathrm{x}$ & 108.9 & 87.0 & 100.3 & 102.6 \\
\hline Agricultural production index & $\mathrm{x}$ & $\mathrm{x}$ & $\mathrm{x}$ & 117.39 & 90.6 \\
\hline $\begin{array}{l}\text { Volume of manufactured building products, } \\
\text { thous UAH }\end{array}$ & 6263182 & $\mathrm{x}$ & $\mathrm{x}$ & $\mathrm{x}$ & $\mathrm{x}$ \\
\hline Building products index & $\mathrm{x}$ & $\mathrm{x}$ & $\mathrm{x}$ & 111.7 & 136.8 \\
\hline Exports of goods, mln USD & $4111.7^{1}$ & $\mathrm{x}$ & $\mathrm{x}$ & $92.2^{4}$ & $110.4^{5}$ \\
\hline Imports of goods, mln USD & $1994.7^{1}$ & $\mathrm{x}$ & $\mathrm{x}$ & $100.1^{4}$ & $110.8^{5}$ \\
\hline Balance $(+,-)$ & $2117.0^{1}$ & $\mathrm{x}$ & $\mathrm{x}$ & $\mathrm{x}$ & $\mathrm{x}$ \\
\hline
\end{tabular}

Source: Holovne upravlinnia statystyky $v$ Donetskii oblasti, 2020 


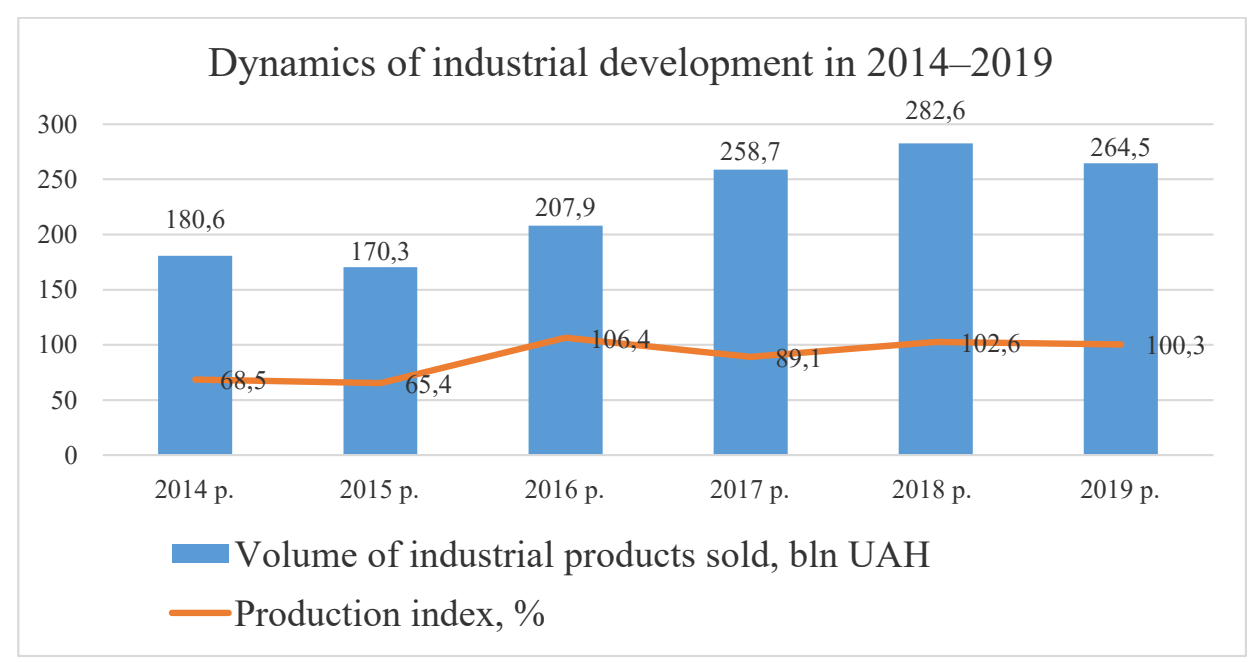

Figure 1. Dynamics of industrial development in 2014-2019

There is a steady downward trend in foreign economic activity. Exports of goods in 2019 decreased by $7.8 \%$ compared to the same period and amounted to $4111.7 \mathrm{mln}$ USD. On the contrary, imports of goods in 2019 increased by $0.1 \%$ and amounted to $1994.7 \mathrm{mln}$ USD.

In 2018, enterprises and organizations of Donetsk oblast will use 21.0 billion UAH of capital investment at the expense of all sources of financing, which is $20.0 \%$ more than in JanuaryDecember 2017 (in comparable prices). The total amount of foreign direct investment attracted to the region's economy has increased compared to the beginning of the year and is expected to reach 1.3 billion USD by the end of 2018 (Prohrama ekonomichnoho i sotsialnoho rozvytku Donetskoi oblasti... ). The difficult, unstable political situation in the country, weak development of market institutions (corporate sector, securities market, land market, real estate market, etc.) remain the main reasons for low direct investment.

Part of Donetsk oblast is currently not controlled by the Government of Ukraine; therefore, the road network has changed in the region, logistical connections have been broken. Thus, the three transport corridors that cross Donetsk oblast from west to east were provided for transit in the direction of the Russian Federation, the Caucasus, and Asia. They are temporarily deadlocked now, which causes a change in the system of infrastructure, logistics of areas that are in the area of influence of these roads.

In addition, the restoration of damaged and destroyed strategic life support facilities located along the demarcation line is complicated by the lack of safe access for specialists to perform restoration and repair due to active hostilities.

\section{Directions of development of "center-region" relations taking into account environmental and economic security}

The analysis shows what socio-economic phenomena have affected the state of development of Donetsk oblast in the six years since the beginning of the armed conflict. This allows to form directions for the development of "center-region" relations taking into account environmental and economic security, namely: the need to develop measures to support industries with a high level of added value; the need to provide financial support to small businesses for the implementation of development projects; implementation of infrastructure rehabilitation and development projects at the expense of budgetary and extra-budgetary funds.

That is, in terms of methodological research, this example confirmed that the regional level of the socio-economic system in the analysis process with a certain degree of accuracy can be considered a quasi-organization, which in turn consists of a number of economic and socioeconomic subsystems interconnected in the process functioning. The number of levels of this subsystem depends on the degree of its complexity and the size of the functional elements included, as well as on the selected features, according to which the system is structured according to Euler's hierarchy. To ensure socio-economic security in the functioning of the economic system under the 
influence of its self-regulation in an unstable and highly volatile environment, the regional level of the socio-economic system must maintain some potential for development on the most important socio-economic and social parameters, which should be applied using systemic approach.

In this regard, there is a methodological task to formulate priority approaches to determining the parameters of socio-economic security of the regional subsystem of the socio-economic system, taking into account the effective functioning of all economic entities, which are located and have economic interests within the region. Despite the widespread use of various indicators in management practice and in everyday life, the unified theory of determining the parameters of socio-economic security of the regional subsystem of the socioeconomic system has not yet been formed.

There are two approaches to the formation of indicators of environmental and economic security of the socio-economic subsystem of the region. The first of them applies the general principles of public administration within the socio-economic system as a whole without the features of environmental and economic security of the region. The second approach identifies the factors of effective development of socioeconomic structures of the regional level, taking into account their possible safe environmental and economic functioning.

To assess the possibilities of development of the regional socio-economic subsystem in terms of its effective functioning within the first approach, the following indicators can be identified: employment rate in the region, which is calculated to determine the impact of unemployment in the region on overall economic reproduction; demographic indicators that make it possible to assess the development potential of labor resources at the regional level of the socioeconomic system; the ratio of the average wage in the region with the subsistence level in order to assess the need to protect social guarantees of the population; comparison of revenues and expenditures to calculate the level of shadowing of the region's economy (Mizhrehionalni terytorialni orhany).

According to the second approach, the following components of economic security of the region are distinguished: economic independence, which determines the possibility of control of regional authorities over the use of available economic and socio-economic resources of the region, taking into account their environmental friendliness; protection of property rights and the formation of conditions and guarantees for entrepreneurial activity (it is necessary to maintain stable relations between the various economic entities that exist in the region, which provides for unshadowing of economic ties and support for small businesses to overcome excessive income differentiation, etc.); achieving the competitiveness of economic entities operating at the regional level to participate in interregional, international and global cooperation; creating conditions for modernization of production through the constant investment of entrepreneurial activity and innovative development, which requires raising the professional, educational and cultural level of the population (Mizhrehionalni terytorialni orhany).

It is on the basis of these approaches that today the theory of public administration is creating a system of indicators of socio-economic development of the region, but these indicators are "residual" in the environmental, economic and socio-economic context if the internal functional contradictions are present in the "center - region" relations. Therefore, there is a need to study within the analysis of the development of the regional subsystem of the socio-economic system of society a set of regional problems, taking into account the possible effects of threats of the functional danger of environmental, economic and socio-economic nature.

\section{Conclusions}

In the most general form, the main indicators of the development of the regional subsystem of the socio-economic system of society in terms of the impact of regional interests on the dynamics of economic indicators of society can be recognized as follows:

- socio-demographic indicators that characterize the level and quality of life of the region's population; - environmental and economic indicators that characterize the ability of the regional economic entities to function at different stages of the process of expanded reproduction of social production; - socio-economic indicators, including those that characterize the situation with food security in the region;

- investment indicators that characterize the ability of the region's industries to carry out structural 
transformations at the organizational and functional level; - institutional indicators that characterize the effectiveness of functional transformations in the socio-political sphere of society, primarily the level of control of economic processes and the effectiveness of unshadowing economic relations and decriminalization of economic entities.

Determining the limit values of these indicators and comparing them can enable public authorities to calculate the so-called "safety zone" of socioeconomic "center - region" relations within the development of socio-economic system in general and its regional level in particular. This will provide an opportunity to choose the best management decisions to ensure the environmental and economic security of the region taking into account maintaining the balance of national interests of the country.
Ensuring the socio-economic development of society is possible by improving the management of the formation of "center - region" relations, based on the study and use of laws and patterns of regional socio-economic development, identifying forms of their implementation to achieve qualitative change in environmental and economic parameters development of the region. The study of the issues of management of the processes of "center region" relations in the presence of the influence of destabilizing factors becomes an urgent task of ensuring the security of the modern regional economy within the socio-economic system.

Given the great scientific and practical significance of this problem, it is advisable to further study the possibilities of "center - region" relations to ensure economic security of the region, taking into account indicators of the regional component of the socio-economic system.

\section{References:}

Heiets, V. M. (2006). Modeliuvannia ekonomichnoi bezpeky: derzhava, rehion, pidpryiemstvo: monohrafiia [Modeling economic gaps: state, region, entrepreneurship]. Kharkiv: INZhEK, 240 p. (in Ukrainian)

Pasternak-Taranushenko, H. A. (2012). Obolonky zakhystu ekonomichnoi bezpeky Ukrainy [Shells to protect the economic security of Ukraine]. Available at: http://www.niss.gov.ua/Table/

Chukhno, A. A. (2007). Stanovlennia evoliutsiinoi paradyhmy ekonomichnoi teorii [The emerging evolutionary paradigms of economic theory]. Kyiv: NDFI, 712 p. (in Ukrainian)

Bondar, O. P. (2013). Zabezpechennia ekonomichnoi bezpeky rehioniv Ukrainy [Ensuring economic security of the regions of Ukraine]. Naukovyi visnyk: finansy, banky, investytsii, no. 4, pp. 94-99.

Hudzynskyi, O. D. (2014). Ryzyky ta ekonomichna bezpeka sotsialno-ekonomichnykh system [Risks of the economic scourge of the social-economic system]. Zbirnyk naukovykh prats Tavriiskoho derzhavnoho ahrotekhnichnoho universytetu (ekonomichni nauky), no. 2(26), pp. 35-37.

Ansell, Ch. (2002). Debating Governance / American Political Science Review, vol. 96, no. 3, pp. 668-669.

Beer, S. (1994). The Heart of Enterprise / Stafford Beer / John Wiley \& Sons, 582 p.

Checkland, P. B. (1976). Towards a system-based methodology for real-world problem-solving // Systems behavior (J. Beison and G.Peters, eds.). L., pp. 51-77.

Prohrama ekonomichnoho i sotsialnoho rozvytku Donetskoi oblasti na 2019 rik ta osnovni napriamy rozvytku na 2020 i 2021 roky [Program of economic and social development of the Donetsk region in 2019 on the basis of basic development programs of 2020 i 2021 deadlines]. Available at: https://dn.gov.ua/ua/ekonomika/programi-rozvitku-regionu/programa-ekonomichnogo-i-socialnogorozvitku

Holovne upravlinnia statystyky v Donetskii oblasti (2020) [Main Department of Statistics in Donetsk region]. Sotsialno-ekonomichne stanovyshche Donetskoi oblasti za 2019 rik: statystychnyi biuleten. Bakhmut, 44 p. (in Ukrainian)

Holovne upravlinnia statystyky v Donetskii oblasti (2019) [Main Department of Statistics in Donetsk region]. Sotsialno-ekonomichne stanovyshche Donetskoi oblasti za 2018 rik: statystychnyi biuleten. Bakhmut, 60 p. (in Ukrainian)

Mizhrehionalni terytorialni orhany [International Territorial Bodies]. Ofitsiinyi veb-portal Derzhavnoi ekolohichnoi inspektsii Ukrainy. Available at: https://www.dei.gov.ua/posts/111 